\title{
Bioremediation of Spent Engine Oil Contaminated Soils Using Indigenous Fungi Species
}

\author{
'Laurelta Tudararao-Aherobo, Solomon Mesogboriwon \\ Department of Environmental Microbiology and Toxicology, Federal University of Petroleum \\ Resources, Effurun, Delta State, Nigeria \\ "Corresponding Author: e-mail : tudararo.aherobo@fupre.edu.ng
}

\begin{abstract}
Spent engine oil is derived from lubricating oil which has been used to lubricate various internal combustion engines and it is drained out for disposal during servicing of the engine. Spent engine oil causes great damage to soil and soil microflora when disposed indiscriminately. Thus, the bioremediation of spent engine oil contaminated soil was studied using indigenous degrading fungi isolated from hydrocarbon contaminated soils obtained from automobile mechanic workshops located at both Okpe and Uvwie Local Government Areas of Delta State, in the Niger Delta region of Nigeria. Three (3) fungi isolates with high engine oil biodegradability potential were used for the spent engine oil (SEO) bioremediation study. The fungi isolates used for the test were identified as, Aspergillus glaucus, Trichoderma polysporum and Talaromyces flavususing the API 20C method. The test microcosms were incubated for four weeks at $28 \pm 2^{\circ} \mathrm{C}$. Physicochemical parameters such as, Sulphate concentrations, Total petroleum hydrocarbon, Nitrate concentrations, Phosphate concentrations, Total organic carbon content, $\mathrm{pH}$ and Hydrocarbon utilizing fungi counts were monitored weekly using standard ASTM methods to assess the biodegradation of the spent engine oil. At the end of the test duration, Talaromyces flavus recorded the highest percentage spent engine oil biodegradation (69.66\%) for the 5\% SEO experimental set up. Similarly, Aspergillus glaucus recorded the highest percentage SEO biodegradation (66.16\%) for the 10\% experimental set up. Thus, Talaromyces flavus and Aspergillus glaucus could be used to effectively bioaugment the bioremediation process of spent engine oil contaminated soils to restore the soil to its original state within a short period of time.
\end{abstract}

Keywords : Spent engine oil contaminated soils, bioremediation and indigenous fungi species.

\section{INTRODUCTION}

In Nigeria, it is common among motor mechanics not to have a specified and appropriate disposal method for spent engine oil used in their various workshop, which leads to disposal into gutters, water drains and soil (Okonokhua, et al., 2007). Spent engine oil is defined as used lubricating oils obtained after servicing and subsequently drained from automobile and generator engines. Spent oils contain high percentage of aromatic and aliphatic hydrocarbons, nitrogen and sulphur compounds and metals such as Manganese, Calcium, Zinc, Lead, than fresh oils. These metals are introduced into the fresh oil as a result of wears and tears of the engine (Mohd, et al., 2011).

Engine oil is described by Klamann (1984) as the oil that principally functions as cleaning the motor engines, lubricating the moving parts of motor 
engines, inhibiting corrosion of motor engines, improving sealing and cooling the engine by transporting heat away from the moving parts. The present day engine oils are derivative of petroleumbased and non-petroleum produced chemical compounds. Engine oils are, therefore, mainly blended by employing base oils composed of hydrocarbons (organic compounds containing carbon and hydrogen exclusively), for instance mineral oil (Corsico, etal., 1999).

Spent engine oil causes great damage to soil and soil microflora. It creates unsatisfactory condition for life in the soil due to poor aeration, immobilization of soil nutrients and lowering of soil $\mathrm{pH}$ (Ugoh and Moneke, 2011). It has been shown that marked changes in properties occur in soil contaminated with hydrocarbon, this affects the physical, chemical and microbiological properties of the soil (Okonokhua, et al., 2007). At low concentrations, some of these heavy metals are essential micronutrients for plants, but they can cause metabolic disorders and growth inhibition when the concentration is at high levels. The key components typical of spent engine oil consist of aliphatic and aromatic hydrocarbons such as phenol, naphthalene, benzo (a) anthracene, benzo (a) pyrene, and fluoranthene (Irwin, et al., 1997). After any oil spillage, Polycyclic Aromatic Hydrocarbons (PAHs) which are component of spent oil, are important contaminant which are retained in the environment. PAHs could disrupt the endocrine system of animals affect (Kathi and Anisa, 2012). Spent Oil has contaminated soils used for agricultural lands and has not spared the aquatic and marine plants and animals in Nigeria. Ground water has also been contaminated hence polluting the crops and farm animals (Eneh, 2011). Therefore, there is the need for bioremediation of spent engine oil (hydrocarbon) contaminated.
Physical, chemical and mechanical processes are traditional methods used in remediation of contaminated areas. Physical remediation method includes incineration, brick making and skimmers etc. This method cannot biodegrade more than $10-15 \%$ of spilled oil (Thavasi, et al., 2011). Use of chemical surfactants as remediating agent on the other hand is not favourable due to their toxic effects on flora and fauna (Thavasi, et al., 2011). However, this type of treatment system requires heavy machinery and the environmental consequences of this pollutant removal may result in massive air pollution (Bhupathiraju, et al., 2002).

Fungi and bacteria are being used for biodegradation of hydrocarbons (Snape, et al., 2001). The filamentous fungi possess some attributes that enable them to be good potential agents of degradation. A fungus attaches itself quickly on the substratum then digests the substratum through the secretions of extracellular enzymes (Okerentugba and Ezeronye, 2003). Fungi are capable of growing under environmental stress including, low $\mathrm{pH}$, poor nutrients and low water activity. Fungal bioremediation is an attractive approach over other techniques like physicalchemical techniques, for it is simple, easy to maintain, cost effective and can be produced in mass (Achal, et al., 2011). It also requires little energy input and preserves the soil structure. Studies by Smita, et al., (2012) shows that, Aspergillus, Penicillium, Fusarium,Rhizopus, Alternaria and Cladosporium species have been identified as effective hydrocarbon biodegraders.

\section{MATERIALS AND METHODS}

\section{A. Collection of Spent Engine Oil}

One (1) litre of spent engine oil was bought from an automobile mechanic workshop located at Okuokoko in Okpe LGA, Delta State (latitude 5.578557, 
longitude 5.830875). It was collected in $1 \mathrm{~L}$ glass bottle and preserved in the refrigerator until required for use. Spent engine oil obtained was filter sterilize with WHATMAN NO 42 filter paper. Its physicochemical properties were analyzed with the following parameters; $\mathrm{pH}$ and total petroleum hydrocarbon (TPH)/total hydrocarbon content (THC) using standard methods of ASTM and APHA.

\section{B. Collection of Hydrocarbon contaminated Soils}

Samples of hydrocarbon contaminated soils were collected from automobiles mechanic workshops located in Uvwie and Okpe Local Government Areas (LGA) of Delta state. Sample A was collected from a workshop at Okuokoko (latitude 5.578557, longitude 5.830875) in Okpe LGA, while sample B was taken from a workshop at Ugbomro (latitude 5.563975, longitude 5.819289) in Uvwie LGA, Delta state.

\section{Collection of Hydrocarbon Uncontaminated (Native) Soil}

Nine (9) kilogrammes of pristine sandy loam was collected from the Federal University of Petroleum Resources, Effurun farm at Ugbomro in Uvwie LGA, Delta state at latitude 5.569708 and longitude 5.844322 and air dried. The dried soil was sieved with a $2 \mathrm{~mm}$ sieve and stored at ambient temperature ready for use. Its physicochemical properties were analyzed with the following parameters; $\mathrm{pH}$, total organic content (TOC), total petroleum hydrocarbon (TPH)/total hydrocarbon content (THC), soil texture, nitrate concentration $\left(\mathrm{NO}_{3}\right)$, phosphate concentration $\left(\mathrm{PO}_{4}{ }^{3-}\right)$, sulphate concentration $\left(\mathrm{SO}_{4}{ }^{2-}\right)$ and heterotrophic fungi counts.

\section{Collection of Compost}

Five (5) kilogrammes of chicken droppings was collected from a poultry at Agbarho in Ughelli North LGA, Delta state at latitude 5.590188 and longitude
5.851524 and air dried. The dried droppings were crushed to tiny particles before use. It was stored at ambient temperature ready for use. The chicken droppings collected was air dried and crumbled into smaller particles. Its physicochemical properties were analyzed with following parameters; $\mathrm{pH}$, total organic content (TOC), total hydrocarbon content (THC), nitrate concentration $\left(\mathrm{NO}_{3}\right)$, phosphate concentration $\left(\mathrm{PO}_{4}{ }^{3-}\right)$, Sulphate concentration $\left(\mathrm{SO}_{4}{ }^{2-}\right)$ and heterotrophic fungi counts according .

\section{E. Isolation of Spent Engine Oil degrading Fungi}

The isolation of spent engine oil degrading fungi was done according to the method ofBhattacharya, et al., (2015). Bushnell-Haas (BH) media with the following composition (g/L): $\mathrm{K}_{2} \mathrm{HPO}_{4}(0.1 \mathrm{~g}), \mathrm{KH}_{2} \mathrm{PO}_{4}(0.1 \mathrm{~g})$, $\mathrm{NH}_{4} \mathrm{NO}_{3} \quad(0.1 \mathrm{~g}), \quad \mathrm{MgSO}_{4} \cdot 7 \mathrm{H}_{2} \mathrm{O} \quad(0.02 \mathrm{~g}), \mathrm{FeCl}_{3} \cdot 6 \mathrm{H}_{2} \mathrm{O}$ $(0.005 \mathrm{~g}), \quad \mathrm{CaCl}_{2} \cdot 2 \mathrm{H}_{2} \mathrm{O} \quad(0.002 \mathrm{~g}), \quad$ was used as enrichment medium with filter sterilize spent engine oil $1 \%(\mathrm{v} / \mathrm{v})$ added as the sole carbon source. The BH media was autoclave at $120^{\circ} \mathrm{C}$ for fifteen (15) minutes and allowed to cool before the soil samples and carbon source were added. Soil samples $(10 \mathrm{~g})$ each, from the two hydrocarbon contaminated sites sampled, were enriched by adding $100 \mathrm{ml} \mathrm{BH}$ media in two $250 \mathrm{~mL}$ Erlenmeyer culture flasks each. It was then stirred and incubated for seven (7) days at $30^{\circ} \mathrm{C}$. The mixture was stirred daily for effective aeration. After seven (7) days incubation, serial dilution of the enriched soil was done using normal saline prepared from $0.85 \mathrm{~g}$ of sodium chloride $(\mathrm{NaCl})$ in $100 \mathrm{ml}$ of distilled water. One (1) $\mathrm{ml}$ each was collected from the supernatant of the two (2) Erlenmeyer culture flasks containing the enriched soil for the serial dilution. Pour plating technique was used for plating inoculum, using $10^{-4}$. And $10^{-5}$. Potato dextrose agar (PDA) was used for the cultivation of fungi. Three (3) drops of acetic acid was added to the PDA to inhibit bacteria growth. The culture was incubated for $3-6$ days at $28 \pm 2^{\circ} \mathrm{C}$. 
Pure fungi cultures was obtained by streaking a single colony on solidified PDA plates. It was allowed to grow for four to six days at $30^{\circ} \mathrm{C}$. Discrete colonies were subculture on PDA slant, allowed to grow for four to six days and then stored in the refrigerator until required for use.

\section{F. Screening and selection of Spent Engine Oil Degrading Fungi}

For the selection of spent engine oil degrading fungi, the isolated fungi pure cultures were screened for effective spent engine oil degradation. The isolates were aseptically put into $100 \mathrm{ml} \mathrm{BH}$ broth in culture flasks with $1 \%(\mathrm{v} / \mathrm{v})$ filter sterilized spent engine oil as carbon source. The flasks were then incubated for 7 days. Turbidity of the culture was read at the end of the incubation period (Mounteer, 2006). Isolates with high turbidity values were selected for the biodegradation tests.

\section{G. Identification of Selected Fungi Isolates}

Screened and selected spent engine oil degrading fungi were identified using API test kit (API 20C method).

\section{H. Spent engine oil Biodegradation Studies}

Three isolates (Aspergillus glaucus,Trichoderma polysporum and Talaromyces flavus) with the highest turbidity values were used for the biodegradation test. The spent engine oil contaminated soil was treated with variable culture conditions which included; incubation period $(0,7,14,21$ and 28 days) and spent engine oil concentration ( 5 and $10 \% \mathrm{v} / \mathrm{v}$ ). $500 \mathrm{~g}$ of the native soil and compost was mixed in a ratio of 3:1. The mixture of native soil and compost was contaminated with $5 \% \mathrm{v} / \mathrm{v}(50,000 \mathrm{mg} / \mathrm{kg})$ and $10 \%$ $\mathrm{v} / \mathrm{v}(100,000 \mathrm{mg} / \mathrm{kg})$ spent engine oil. $20 \mathrm{ml}$ of the activated isolates in $\mathrm{BH}$ medium was added to the soil, compost and spent oil mixture. $50 \mathrm{ml}$ of distilled water was added at four (4) days intervals days to maintain the moisture content of the soil. A control containing only the soil and spent oil, devoid of the isolates and compost was prepared along with the test. The degradation microcosm was prepared in duplicates. Biodegradation of the spent engine oil in the test microcosms was assessed and monitored weekly $(0,7$, 14, 21 and 28days) for four (4) weeks. The biodegradation of the spent oil was monitored by analyzing the following physicochemical and microbiological parameters in the test soils; $\mathrm{pH}$, total organic content (TOC), total petroleum hydrocarbon(TPH)/total hydrocarbon content(THC), Nitrate concentration $\left(\mathrm{NO}_{3}{ }^{-}\right), \quad$ Phosphate concentration $\left(\mathrm{PO}_{4}{ }^{3-}\right)$, Sulphate concentration $\left(\mathrm{SO}_{4}{ }^{2-}\right)$ and hydrocarbon utilizing fungi counts (Bhattacharya, et al., (2015).Standard ASTM methods were used for the physicochemical parameters analysis.

\section{Statistical Analysis}

Analysis of variance (ANOVA) was used to determine if there is any significant difference between the sample treatments and between the control and treatments. It was calculated using libre calc version 6.0.6.2 on linux OS 4.15.

\section{RESULTS AND DISCUSSION}

\section{A. Mean Concentration of Physicochemical Parameters of Native Soil}

This result showed that the concentration of total petroleum hydrocarbon in the native soil was below the detection limit of the measuring equipment. This result shows that the concentration of total petroleum hydrocarbon in the native soil is low/negligible. The native soil have a neutral $\mathrm{pH}(7.09 \pm 0.21)$. The nutrient content in the native soil reveals a high concentration of phosphate(7.66 $\pm 0.04 \%)$, a lower concentration of nitrate $(0.029 \pm 0.14 \mathrm{ppm} / \mathrm{kg})$ and a low concentration of sulphate $(0.974 \quad \pm$ $0.40 \mathrm{ppm} / \mathrm{kg}$ ) .The soil texture was sandy loam, which 
is suitable for the bioremediation process (ref). The hydrocarbon utilizing fungi counts werelow $(1.00 \mathrm{x}$ $10^{3} \pm 0.15 \mathrm{CFU} / \mathrm{g}$ ). This counts in the native soil, is corroborated by findings ofRitz, et al., 2003, who stated that bacteria and fungi counts in a given soil could range from $10^{3}$ to $10^{4} / \mathrm{g}$.

B. Mean Concentration of Total Petroleum

\section{Hydrocarbon of Spent Engine Oil}

TPH value obtained for the spent engine oil was 2953 $\pm 2.24 \mathrm{mg} / \mathrm{l}$. The result shows a very high concentration of total petroleum hydrocarbon in the spent oil used for the biodegradation test.

According to Leahy and Colwell (1990), the rates of uptake and mineralization of many organic compounds by microbial populations present in the environment are largely proportional to the concentration of the compound itself. High concentrations of hydrocarbons can inhibit biodegradation by nutrient or oxygen limitation or through toxic effects exerted by volatile hydrocarbons. There is the possibility that if the concentration of oil is high, negative effects on biodegradation rates following oil spills in quiescent, low-energy environments such as beaches, harbours, and small lakes or ponds, in which the oil is relatively protected from dispersion by wind and wave action would be experienced (Leahy and Colwell, 1990).

\section{Mean Concentration of Physicochemical Parameters of Compost}

The total petroleum hydrocarbon in the compost used for the experimental design was below the detection limit of the test equipment, indicating the absence of hydrocarbon contamination. $9.08 \pm 0.22$ was recorded for $\mathrm{pH}$. This indicates that the compost is basic with a moderate hydrocarbon utilizing fungi count of $1.20 \mathrm{x}$ $10^{3} \mathrm{CFU} / \mathrm{g}$. The nutrients concentration reveals a high nutrient content for sulphate with a value of $81.45 \mathrm{ppm}$. Nitrate and phosphate recorded $2.25 \mathrm{ppm}$ and 5.39ppm respectively. The high nutrient content of the compost will biostimulate the growth of the hydrocarbon degrading fungi in the test microcosms ((Nduka, 2012).

\section{Results obtained for Identification of selected Fungi Isolates}

The three selected fungi isolates with high spent engine oil biodegradative ability isolated from hydrocarbon contaminated soils were identified using the characteristics shown in the table 2 below.Asrecorded using the API 20C method, the fungi wereidentified asAspergillus glaucus, Trichoderma polysporum and Talaromyces flavus. These fungi have been known todegrade hydrocarbons and organic compounds (Obire, et al., 2008).

\section{E.Hydrocarbon Utilizing Fungi counts inspent engine oil degradation microcosms}

As shown in figure 1 below, there was anincrease in the fungi counts from Day 0 to Day 28 in both spent engine oil concentrations ( $5 \%$ and $10 \%$ ) for the three fungi isolates used, in relation to the counts in the control. On day 0 , for the $5 \%$ SEO test microcosms, counts ranged from $5.80 \times 10^{5} \mathrm{FU} / \mathrm{g}$ (Aspergillus glaucus) to8.0 × $10^{8} \mathrm{CFU/g}$ (Talaromyces flavus), while on day 28, fungi counts ranged from $5.0 \times 10^{7} \mathrm{CFU} / \mathrm{g}$ Trichoderma polysporum) to $5.80 \times 10^{9}$ CFU/g (Talaromyces flavus). The control recorded a slight increase in count from $3.62 \times 10^{3} \mathrm{CFU}$ on day 0 to $4.80 \times 10^{5} \mathrm{CFU} / \mathrm{g}$ on day 28 . The counts recorded on day $\mathrm{O}$ for the $10 \%$ SEO microcosms, ranged from 5.40 x $10^{5} \mathrm{CFU} / \mathrm{g}$ (Trichoderma polysporum) to $6.80 \mathrm{x}$ 105(Aspergillus glaucus),whilethecounts for day28, ranged from $4.50 \mathrm{x} \quad 10^{6} \mathrm{CFU} / \mathrm{g}$ (Trichoderma polysporum) to $6.40 \mathrm{x} \quad 10^{7} \mathrm{CFU} / \mathrm{g} \quad$ (Aspergillus glaucus).The control recorded a decline in fungi growthfrom $4.0 \times 10^{3} \mathrm{CFU} / \mathrm{g}$ to $2.80 \times 10^{3} \mathrm{CFU} / \mathrm{g}$ at the end of 28 days test period. Thus, Talaromyces flavus recorded the highest count for the 5\% test microcosms, while Aspergillus glaucus recorded the 
highest count for the $10 \%$ microcosms. The control recorded the lowest count in both test concentrations. Theenhanced counts of the fungi in the SEO test soils, could be attributed to the effects of bioaugmentation with the fungi isolates and biostimulation with compost, which must have enhanced the biodegradative potentials of the microorganisms, as well as the improved soil texture by the compost (Smita, et al., 2012).Adding compost to contaminated soil have been shown to enhance bioremediation because of the structure of the organic compost matrix (Kastner and Mahro, 1996). Compost has also be shown to enhance the oxidation of aromatic contaminants in soil to ketones and quinones, which eventually disappear (Wischmann and Steinhart, 1997).

\section{F. Concentration of \% Total Petroleum Hydrocarbon degraded in the SEO contaminated soils.}

From figure 2 below, it was discovered that at 5\%v/v spent engine oil contamination, the sequence of $\%$ degradation of the spent engine oil at Day 28 was; Talaromyces flavus (69.66\%) >Aspergillus glaucus (52.76\%) > Trichoderma polysporum (36.88\%).The control microcosm recorded $20.50 \%$ SEO degradation. At $10 \% \mathrm{v} / \mathrm{v}$ spent engine oil contamination, spent engine oil \% degradation sequence at Day 28 was; Aspergillus glaucus (66.16\%) >Talaromyces flavus (50.61\%) > Trichoderma polysporum(40\%), with Control showing the least percentage degradation (15.33\%). This indicates that Talaromyces flavus degraded the $5 \% \mathrm{v} / \mathrm{v}$ spent engine oil contamination the most, while Aspergillus glaucusdegraded the $10 \% \mathrm{v} / \mathrm{v}$ spent engine oil contamination the most. These findings coroborates with the fungi counts recordedin subsection $G$ above. In previous studies similar results were obatained by Husaini et al. (2008).

\section{G. Mean Concentration of $\mathrm{pH}$ of the SEO biodegradation soils studies.}

For the 5\%v/v SEObiodegradation soils studies, the highest $\mathrm{pH}$ value was recorded for Isolate $\mathrm{J}$ (Aspergillus glaucus) at Day 21 (7.76) and the lowest is Isolate G (Talaromyces f,lavus) at Day 14 (5.93). The Control had the highest value on Day 28 (6.18), showing that the biodegradation has a neutral $\mathrm{pH}$ value. At $10 \% \mathrm{v} / \mathrm{v}$ spent engine oil contamination, Isolate G (Talaromyces flavus) at Day 28 (8.82) and Isolate J (Aspergillus glaucus) at Day 14 (6.51) has the highest and lowest $\mathrm{pH}$ value respectively, with the Control highest value at Day 28 (7.17) (Figure 3). This shows that the biodegradation of the spent oil in the control has a neutral $\mathrm{pH}$ value, while the test set up with the $5 \%$ and $10 \%$ spent oil concentration affected the biodegradation process tended towards alkaline and acidic. The values were however within the recommended $\mathrm{pH}$ range of $6.5-8.0$. The results of the present study are partly consistent with those obtained by Atlas and Bragg (2009).

\section{H. Mean Concentrations of Nutrients in SEO biodegradation soils studies.}

The mean concentration recorded for phosphate at the end of the test duration in the $5 \% \mathrm{v} / \mathrm{v}$ SEO biodegradation test soils, ranged from $3.88 \%$ (Talaromyces f,lavus)to 5.38\%)Trichoderma polysporum) while in the test microcosms with $10 \%$ SEO concentrations, values obtained ranged from 3.80\% (Aspergillus glaucus) to $4.47 \%$ (Trichoderma polysporum).

The mean concentrations recorded for sulphate in the 5\% SEO biodegradation test soils ranged from $1.125 \mathrm{ppm}$ in the test microcosm with Aspergillus glaucusto $1.562 \mathrm{ppm}$ in the test microcosm with Talaromyces flavus, at the end of 28 days.In the $10 \%$ SEO biodegradation test soils,concentrations of sulphate rangedfrom $7.47 \mathrm{ppm}$ in the test microcosm with Trichoderma polysporumto $12.15 \mathrm{ppm}$ in the test 
microcosm with Talaromyces flavus at the end of the test period.The sulphate nutrient was more readily available at the $5 \%$ concentration than in the $10 \%$ test microcosms.

Concentrations recorded for nitrate in the 5\% SEO test microcosms at the end of the test period, ranged from $0.139 \mathrm{ppm}$ (Trichoderma polysporum) to 0.345ppm (Aspergillus glaucus). In the 10\% SEO test soils, concentrations ranged from $0.161 \mathrm{ppm}$ in the microcosms with Trichoderma polysporum to $0.973 \mathrm{ppm}$ in the microcosm with Aspergillus glaucus. The control test soils recorded $0.029 \mathrm{ppm}$ and $0.068 \mathrm{ppm}$ for the $5 \%$ and $10 \%$ at the end of the test period. In the three nutrients monitored it was observed that the there was a higher availability in the 5\% SEO biodegradation test soils than the $10 \%$ SEO test soils.Alexander, et al. (1982) reported that a C: N: P ratio of 100:10:2 was enough to ensure optimal growth of microorganisms. However, some of these nutrients in surplus or limited amounts could become limiting factors, therefore, affecting the process of biodegradation (Zhu etal., 2001; Nilanjana and Preethy, 2010). Hence at higher SEO concentration(10\%), availability of nutrients could have been impaired.

\section{STATISTICAL ANALYSIS RESULTS}

The values computed showed the ANOVA for the percentage TPH degradation of the Isolates in relation to the control At alpha level of 0.05 , the $F$ value (1.310) is lesser than the F critical (2.423), which indicate that there is no significance difference in TPH concentrations among the group means of the two SEO concentrations tested.

The ANOVA for the $\mathrm{pH}$ of the Isolates with their Control, at alpha level of 0.05 , the F value (5.566) is greater than the $\mathrm{F}$ critical(2.313) which indicate that there is a significance difference among the group(treatment) means. The ANOVA for the hydrocarbon utilizing fungi Isolates in relation to the Control, at alpha level of 0.05 , the $F$ value $(0.758)$ is lesser than the $\mathrm{F}$ critical(2.313) which indicate that there is no significance difference among the group means.

Table 1 : Colonial and morphological of identification of fungi isolates

\begin{tabular}{|l|l|l|l|}
\hline Isolates & Colonial Appearance & Morphology & Identity \\
\hline $\mathrm{J}$ & $\begin{array}{l}\text { Felt-like green with brownish top. } \\
\text { Reverse was slightly yellowish. }\end{array}$ & $\begin{array}{l}\text { Conidiophores were of different sizes in } \\
\text { length and were smooth. Sterigmata are } \\
\text { single, radiate columnar. }\end{array}$ & $\begin{array}{l}\text { Aspergillus } \\
\text { glaucus }\end{array}$ \\
\hline $\mathrm{B}$ & $\begin{array}{l}\text { Slightly raised aerial mycelium with } \\
\text { whitish colonies and whitish border. }\end{array}$ & $\begin{array}{l}\text { Oblong and smooth conidia, with long } \\
\text { straight phialides, typically flask- } \\
\text { shaped and enlarged in the middle. }\end{array}$ & $\begin{array}{l}\text { Trichoderma } \\
\text { polysporum }\end{array}$ \\
\hline G & $\begin{array}{l}\text { Fast growing colonies of higher aerial } \\
\text { mycelia, having beautiful mat-like } \\
\text { appearance with creamish colour. } \\
\text { Reverse side was tan. }\end{array}$ & $\begin{array}{l}\text { Conidiophores were borne from aerial } \\
\text { mycelium with bi-verticillate } \\
\text { appearance. The metulae were in } \\
\text { verticils having collula which lappers } \\
\text { gradually with conidia. }\end{array}$ & $\begin{array}{l}\text { Tlavus } \\
\text { flaces }\end{array}$ \\
\hline
\end{tabular}




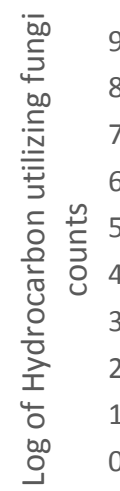

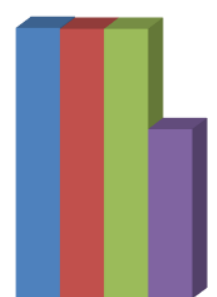

Day 0

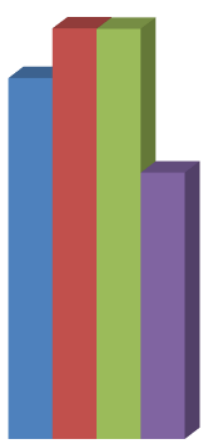

Day 28

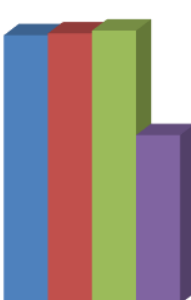

Day 0

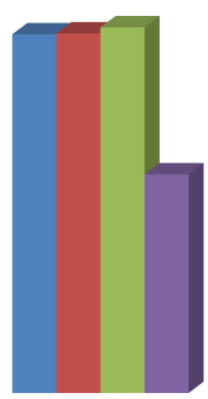

Day 28

$5 \%$

$10 \%$

- Trichoderma polysporum

- Talaromyces flavus

Aspergillus glaucus

- Control

Fig 1: Counts of Hydrocarbon utilizing fungi species in spent engine oil degradation microcosms

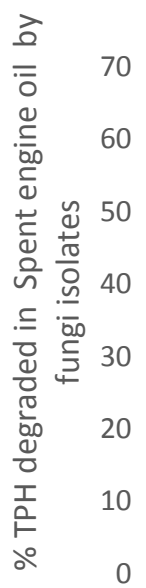

0

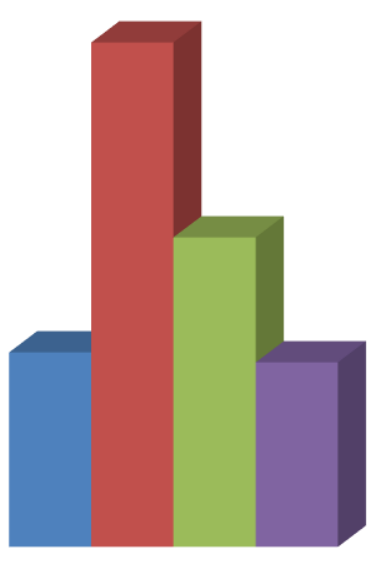

Day 28

$5 \%$

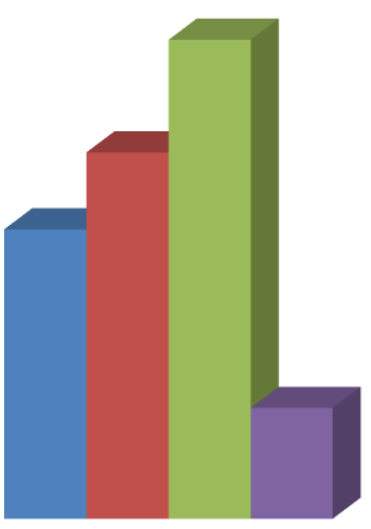

Day 28

$10 \%$

Fig 2: \% TPH degraded in spent engine oil contaminated soils by fungi species. 


\section{Chart showing $\mathrm{pH}$ readings of the degradation process}

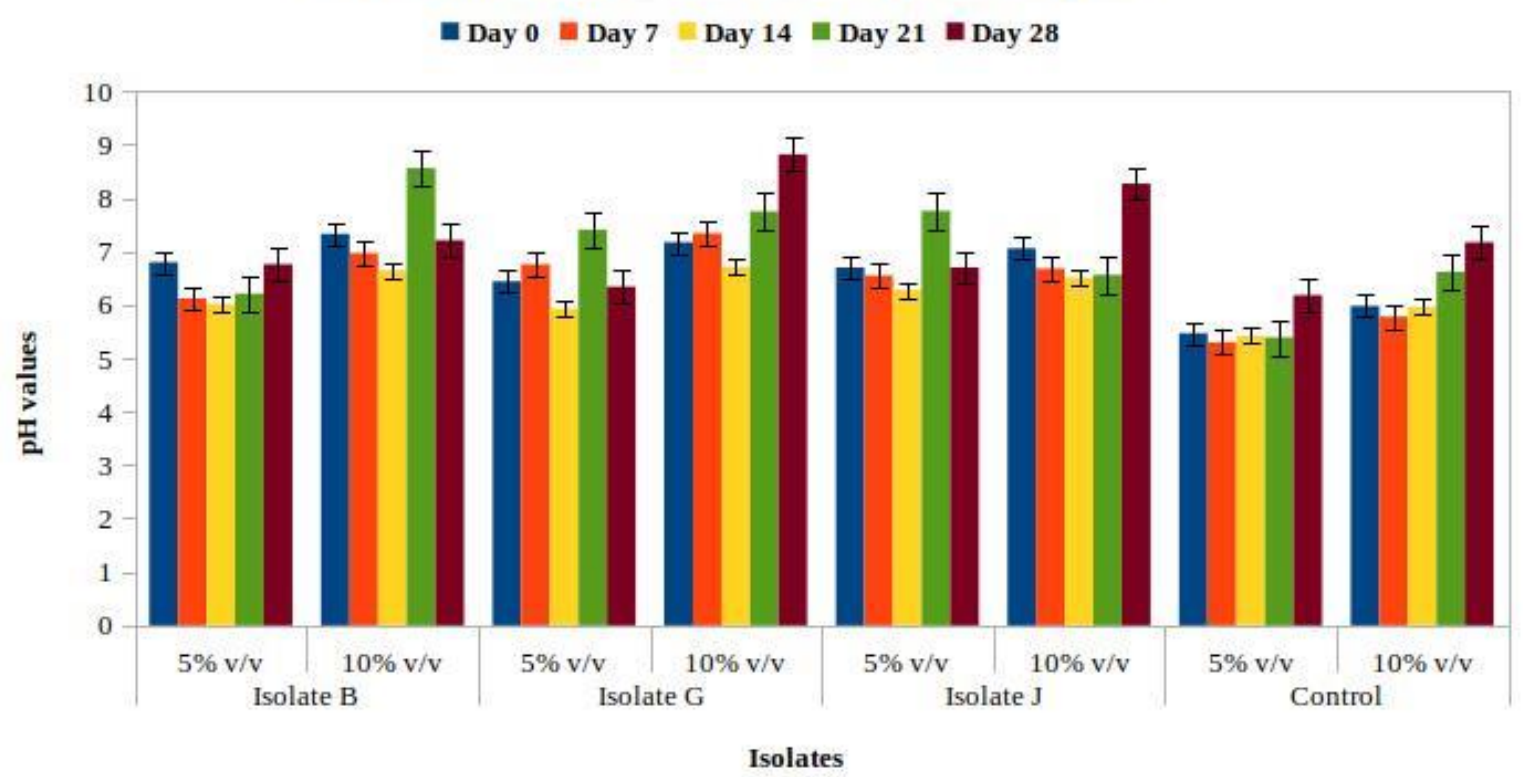

Fig 3: Mean $\mathrm{pH}$ values of Spent engine oil biodegradation soils.

\section{v. CONCLUSION}

The numerous reports and cases of oil spill though devastating is a major challenge which has been overcome by environmental scientists and researchers, adopting bioremediation technique which is cheap and more environmentally friendly compared to other forms of remediation. Bioaugmentation strategies, have been successfully utilized for the bioremediation of refined petroleum products by some researchers. It was successfully utilized in this research to bioremediate spent engine oil contaminated soil.

A total of three fungal isolates were isolated and characterized morphologically from hydrocarbon polluted soils from auto mechanic workshops in both Uvwie and Okpe Local Government Area of Delta state namely, Trichoderma polysporum, Aspergillus glaucus and Talaromyces flavus. The three isolates were identified using the API 20C test method. However for the percentage degradation of spent engine oil, Aspergillus glaucus degraded the the 10\% treatments most with $66.16 \%$, while Talaromyces flavus degarded the $5 \%$ treatments most with $69.66 \%$. Further studies could be conducted to optimize the growth of these fungi on a large scale, preserved in a dehydrated form and in the event of a spill would be rehydrated to promptly remediate the polluted site in the Niger Delta.

\section{REFERENCES}

[1]. Achal, V., Kumari, D. and Pan, X. (2011). Bioremediation of Chromium Contaminated Soils by a Brown Rot Fungus, Gloeophyllum sepiarum. Journalof Microbiology, Vol. 6, 166171.

[2]. Adams, G.O, Tawari-Fufeyin, P and Igelenyah, E. (2014).Bioremediation of Spent Oil Contaminated SoilsUsing Poultry Litter. 
Research Journal of Engineering and Applied Science, Vol.3(2), 124-130.

[3]. Adams, N., Carroll, D., Madalinski, K., Rock, S., Wilson, T. and Pivetz, B. (2000). Introduction to Phytoremediation. National Risk ManagementResearch Laboratory, Office of Research and Development, USEPA,Cincinnati, Ohio

[4]. Adeleye, A.O, Yerima, M.B, Nkereuwem, M.E and Onokebhagbe, V.O. (2017). Biostimulatory Effects ofOrganic Nutrients on Spent Engine Oil andHydrocarbon Related Soil Pollution: A Review. InternationalJournal of Applied Research in Technology, Vol. 6(7), 52-60.

[5]. Adelowo, O.O., Alagbe, S.O. and Ayandele, A.A. (2006). Time-Dependent Stability of Used Engine Oil Degradationby Cultures of Pseudomonas fragi and Achromobacteraerogenes. African Journal of Biotechnology, Vol. 5(24), 2476-2479.

[6]. Ahearn, D.G. and Meyers, S.P. (1976). Fungal Degradation of Oil in the Marine Environment. Gareth Jones (eds). Recent Advances in Aquatic Mycology, Vol. 5, 127-130.

[7]. Ajisebutu, S.O. (1984). Structural and PhysiologicalChanges Induced by Crude Oil Hydrocarbons in SomeSpecies of Marine Bacteria. $\mathrm{PhD}$ Thesis. Available athttps://link.springer.com/article/10.1007/BF00 694313.(Accessed on 6th November, 2017).

[8]. Ajisebutu, S.O. and Alofe, F.V. (2001). The Biotechnology of OilSpillage Treatment: Bioremediation. Science ResearchAnnals. Vol. 1(1), 54-60.

[9]. Alexander, M. (1994). Biodegradation and Bioremediation. Academic, Boston.

[10]. Atagana, H., Haynes, R. and Wallis, F. (2003). The Use of Surfactants as Possible Enhancers in Bioremediation of Creosote Contaminated Coil. Water, Air and Soil Pollutiion, Vol. 142, 137149
[11]. Alexander, S.K. Schropp, S.J. and Schwarz, J.R. (1982). Spatialand Seasonal Distribution of Hydrocarbon-UtilizingBacteria of Sediment from the Northwestern Gulf ofMexico. Contribution in Marine Science, Vol. 25, 13-19.

[12]. American Public Health Association (APHA), (1992).Standard Methods for the Examination of Water andWastewater. 18th Edition, American Public Health Association (APHA), American Water Works Association (AWWA) and Water Pollution Control Federation (WPCF), Washington, DC.

[13]. Antizar-Ladislao, B., Spanova, K., Beck, A.J. and Russell, N.J. (2008). Microbial Community Structure Changes During Bioremediation of PAHs in an Aged Coal-Tar Contaminated Soil by In-Vessel Composting. International Biodeterioration and Biodegradation, Vol. 61, 357-364

[14]. Arabatzis, M. and Velegraki, A. (2013). Sexual Reproduction in the Opportunistic Human Pathogen: Aspergillus terreus. Mycologia Vol. 105, 71-179.

[15]. Atlas, R. and Bragg, J. (2009). Bioremediation of Marine Oil Spills: When and When Not-The Exxon Valdez Experience. Microbial Biotechnology Journal,Vol. 2, 213-221.

[16]. Atlas, R.M. (1981). Biological Degradation of PetroleumHydrocarbons: An Environmental Perspective.Microbiology Vol. 45, 180-209.

[17]. Aust, S.D., Swaner, P.R. and Stahl, J.D. (2003). Detoxification and Metabolism of Chemicals by White-rot Fungi. Pesticide Decontamination and Detoxification. Oxford University Press, Washington, D.C, 3-14.

[18]. Baker, K., and Herson, D. (1994). Bioremediation. McGraw-Hill, New York.

[19]. Balba, M.T., Al-Daher, R., Al-Awadhi, N., Chino, H. and Tsuji,H. (1998). Bioremediation of Oil-ContaminatedDesert Soil: The Kuwaiti 
Experience. EnvironmentInstitute, Vol. 24(1/2), 163-173.

[20]. Barathi, S. and Vasudevan, N. (2001). Utilization of Petroleum Hydrocarbons by Pseudomonas fluorescens Isolated from a Petroleum-Contaminated Soil. Journal of Environment International, Vol. 26, 413-416.

[21]. Barr, D.P., and Aust, S.D. (1994). Mechanisms White Rot fungi Use to Degrade Pollutants. Journal of Environmental Science and Technology, Vol. 28, 354-360.

[22]. Bartha, R. and Atlas, R.M. (1977). The Microbiology of Aquatic Oil Spills. Journal of Advanced Applied Microbiology, Vol. 22, 225266.

[23]. Bhatnagar, D., Cleveland, T.E. and Payne, G.A. (2000). Encyclopedia of Food microbiology, Academic Press, London.

[24]. Bhattacharya, D., Sarma, P.M., Krishnan, S., Mishra, S. and Lal, B. (2002). Evaluation of Genetic Diversity Among Pseudomonas citronellolis Strains Isolated from Oily SludgeContaminated Sites. Applied Environmental Microbioliogy, Vol. 69(3), 1435-1441.

[25]. Bhupathiraju, V.K., Krauter, P., Holman, H.Y.N., Conrad, M.E., Daley, P.F.,Templeton, A.S., Hunt, J.R., Hernandez, M., and AlvarezCohen, L.(2002). Assessment of in-situ Bioremediation at a Refinery Waste Contaminated Site and an Aviation Gasoline Contaminated Site. Journal ofBiodegradation, Vol. 13, 79-90.

[26]. Bossert, I. and Bartha, R. (1984). The Fate of Petroleum in Soil Ecosystems. Atlas RM (ed) Petroleum microbiology, Macmillan, New York, 435-473.

[27]. Braddock, J.F., Ruth, M.L. and Catterall, P.H. (1997).Enhancement and Inhibition of Microbial Activity inHydrocarbonContaminated Arctic Soils: Implicationsfor Nutrient-

Amended
Bioremediation.Environmental Science and Technology, Vol.31, 2078-2084.

[28]. Bragg, J.R., Prince, R.C., Wilkinson, J.B. and Atlas, R.M. (1992).Bioremediation for Shoreline Cleanup Following the1989 Alaskan Oil Spill. Exxon Co., Houston, Texas.

[29]. Braun, R.L. and Burnham, I.K. (1993). Chemical Reaction Modelfor Oil and Gas Generation from Type I and Type IIKerogen. Lawrence Livermore National Laboratory.Available at http://www.osti.gov/bridge/servlets/purl/101691 54-cT5xip/10169154.PDF.

(Accessed onFebruary 29, 2017.)

[30]. Butler, C.S. and Mason, J.R. (1997). StructureFunction Analysisof the Bacterial Aromatic Ring-HydroxylatingDioxygenases. Advance Microbiology and Physiology, Vol. 38, 47-84.

[31]. Callot, H.J. and Ocampo, R. (2000). Geochemistry ofPorphyrins. The Porhpyrin Handbook Vol. 1,Academic, San Diego, California, 349-398.

[32]. Cerniglia, C.E. and Setherland, J.B. (2001). Bioremediation of Polycyclic Aromatic Hydrocarbons by Lignolytic and Non-Lignolytic Fungi. Fungi in Bioremediation. Gadd, G.M. (eds), Cambridge University Press, Cambridge.

[33]. Chaineau, C.H., Morel, J.L., and Oudot, J. (1997). Phytotoxicity of Plant Uptake of Fuel Oil Hydrocarbons. Journal of Environmental Quality, Vol. 26, 1478-1483.

[34]. Chicarelli, M.I., Eckardt, C.B., Owenn, C.R., Maxwell, J.R.,Eglington, G., Hutton, R.C. and Eaton, A.N. (1990).Application of Inductivity Coupled Plasma MassSpectrometry in the Determination of OrganometallicCompounds in Chromatographic Fractions fromOrganic Rich Shales. Organic Geochemistry, Vol.15, 26-274.

[35]. Chikere, C.B., Okpokwasili, G.C. and Chikere, B.O. (2009).Bacterial Diversity in a Tropical Crude Oil PollutedSoil Undergoing 
Bioremediation. Africa Journal of Biotechnology, Vol. 8,2535-2540.

[36]. Chris, C. (2007). Implementing Phytoremediation ofPetroleum Hydrocarbons. Methods in Biotechnology, Vol. 23, 99-108.

[37]. Daugulis, A. and McCracken, C.M. (2003). MicrobialDegradation of High and Low Molecular WeightPolyaromatic Hydrocarbons in a Two-PhasePartitioning Bioreactor by Two Strains ofSphingomonas sp. Biotechnology Letters, Vol.25(17),1441-4.

[38]. Chroma, L. (2002). Enzymes in Plant Metabolism of PCBs and PAHs. Journal of Acta Biotechnologica, Vol. 22, 35-41.

[39]. Colwell, R.R., Walker, J. D. and Cooney, J. J. (1977). Ecological Aspects of Microbial Degradation of Petroleum in the Marine Environment. CriticalReviews in Microbiology, Vol. 5, 423-445.

[40]. Corsico, G., Mattei, L., Roselli, A. and Gommellini, C. (1999). Poly (internal olefins) Synthetic Lubricants and High-Performance Functional Fluids. Marcel Dekker, Chapter 2, 53-62, ISBN: 0-8247-0194-1.

[41]. Das, K. and Mukherjee, A.K. (2007). Crude Petroleum Oil Biodegradation Efficiency of Bacillus subtilis and Pseudomonas aeruginosa Strains Isolatedfrom Petroleum Oil Contaminated Soil from North-East India. Journal ofBioremediation and Technology, Vol. 98, 1339-1345.

[42]. Davis, J.B. and Westlake, D.W.S. (1979). Crude Oil Utilization by Fungi. Canada Journal of Microbiology, Vol. 25, 146-156.

[43]. Desai, A. and Vyas, P. (2006). Applied Microbiology inPetroleum and Hydrocarbon Microbiology.Department of Microbiology, University ofBaroda .Vadodara 390 002, 13Apr-2006 (Revised 6-Dec-2006), 1-22.

[44]. Déziel, E., Comeau, Y. and Villemur, R. (1999). Two-liquid-phase Bioreactors for Enhanced
Degradation of Hydrophobic/Toxic Compounds. Biodegradation, Vol. 10, 219-233.

[45]. Dominati, E., Patterson, M. and MacKay, A. (2010). A Framework for Classifying and Quantifying Natural Capital and Ecosystem Services of Soils. Ecological Economics, Vol. 69, 1858-1868.

[46]. Dominiquez, E., Pitchel, E. and Coughlin, M. (2014). Phytoremediation of Soil Contaminated with Used Motor Oil: Enhanced Microbial Activities from Laboratory and Growth Chamber Studies. Environmental Engineering and Science, Vol. 21, 157-168.

[47]. Eneh, O.C. (2011). A Review On Petroleum: Sources, Uses, Processing, Products And The Environment. Journal of Applied Science, Vol. 11, 2084-2091.

[48]. Fatuyi, O.E., Oluwatoyin, F.O. and Esther, A.E. (2012). Biodegradation of Bonnylight Crude Oil by Locally Isolated Fungi from Oil Contaminated Soils in Akure, Ondo state. Malaysian Journal of Microbiology, Vol. 8, 4246.

[49]. Frick, C.M., Farrell, R.E. and Germida, J.J. (1999). Assessment ofPhytoremediation as an in-situ Technique for CleaningOilContaminated Sites. Report submitted toPetroleum Technology Alliance of Canada. Availableat

https://cluin.org/download/remed/phyassess.pdf .(Accessed on 5th November, 2017).

[50]. Gadd, G.M. (2010). Metals, Minerals and Microbes: Geomicrobiology and Bioremediation. Microbiology, Vol. 156, 609643

[51]. Gadd, G.M. (2001). Fungi in Bioremediation. Cambridge University Press, Cambridge.

[52]. Gibson, A.M., Baranyi, J., Pitt, M.J., Eyles, M.J. and Roberts, T.A. (1994).Predicting Fungal Growth: The Effect of Water Activity on Aspergillus flavusand Related Species. 
International Journal for Food Microbiology, Vol. 23, 419-431.

[53]. Hach Company (1992). Hach Water Analysis Handbook.Available

athttps://www.hach.com/wah. (Accessed on 5thNovember, 2017).

[54]. Hagwell, I.S., Delfino, L.M. and Rao, J.J. (1992). Partitioning ofPolycyclic Aromatic Hydrocarbons from Oil intoWater. Environmental Science and Technology, Vol. 26, 2104-2110.

[55]. Hamamura, N., Olson, S.H., Ward, D.M. and Inskeep, W.P.(2006). Microbial Population Dynamics Associatedwith Crude Oil Biodegradation in Diverse Soils. AppliedEnvironmental Microbiology, Vol.72, 6316-6324.

[56]. Haught, R.C., Neogy, R., Vonderhaar, S.S., Krishnan, E.R., Safferman, S.I. and Ryan, J. (1995). Land Treatment Alternatives for Bioremediating Wood Preserving Wastes. Hazard Waste Hazard Mater, Vol. 12, 329-344.

[57]. Hornback, J.M. (1998). Organic Chemistry. Brooks/ColePublishing, Pacific Grove, California.

[58]. Huesemann, M.H. and Moore, K.O. (1993). CompositionalChanges during Landfarming of Weathered MichiganCrude Oil-Contaminated Soil. Journal of Soil Contamination, Vol.2, 245246.

[59]. Husaini, A., Roslan, H.A. and Hii, K.S.Y. (2008). Biodegradation of Aliphatic Hydrocarbon by Indigenous Fungi Isolated from Used Motor Oil Contaminated Sites. World Journal of Microbiology and Biotechnology, Vol. 24, 27892797.

[60]. Iranzo, M., Sainz- Pardo, I., Boluda, R., Sánchez, J., and Mormeneo, S. (2001). The Use of Microorganisms in Environmental Remediation. Annuals ofMicrobiology, Vol. 51, 135-143.
[61]. Irwin, R.J., Van-Mouwerik, M., Stevens, L., Seese, M.D. andBasham, W. (1997). Environmental ContaminantsEncyclopedia. National Park Service, WaterResources Division, Fort Collins, Colorado.

[62]. Ismail, H.Y, Ijah, U.J.J., Riskuwa, M.L. and Allamin, I.I. (2014).Biodegradation of Spent Engine Oil by Bacteria Isolated from the Rhizosphere of Legumes grown inContaminated Soil. International Journal of Environment, Vol.3(2), 63-75.

[63]. Jarv, H., Lehtmaa, J., Summerbell, R.C., Hoekstra, E.S., Samson, R.A. and Naaber, P. (2004). Isolation of Neosartorya pseudofischeri from Blood: FirstHint of Pulmonary Aspergillosis. Journal of Clinical Microbiology,Vol. 42, 925-928.

[64]. Jones, E.B.G. (1976). Recent Advances in Aquatic Mycology. Elek, London, 749.

[65]. Kästner, M. and Mahro, B. (1996). Microbial Degradation of Polycyclic Aromatic Hydrocarbons in Soils Affected by the Organic Matrix of Compost. Applied Microbiology and Biotechnology, Vol. 44, 668-675.

[66]. Kathi, S. and Anisa, B.K. (2012). Isolation and Characterization of Polycyclic Aromatic Hydrocarbon Degrading Soil Microbes from Automobile Workshop Sediments. Journal of Environmental Science and Technology, Vol. 5, 74-83.

[67]. Kearney, P. and Wauchope, R. (1998). Disposal Options Based on Properties of Pesticides in Soil and Water. Pesticide Remediation in Soils and Water, Wiley Series in Agrochemicals and Plant Protection, Wiley, New York.

[68]. Klamann, D (1984). Lubricants and Related Products, Verlag Chemie, Weinheim, Deerfield Beach (Florida) and Basel. Available at https://lib.ugent.be/en/catalog/rug01:000701193 . (Accessed on 4th November, 2017). 
[69]. Kvenvolden, K.A. (2006). Organic Geochemistry - A Retrospective of its First 70 years. OrganicGeochemistry, Vol. 37, 1.

[70]. Kwaspisz, E, Wszelaka, J, Marchut, O. and Bielecki, S. (2008).The Effect of Nitrate and Ammonium Ions on Kineticsof Diesel Oil Degradation by Gordonia alkanivoransS7. International Biodeterioration andBiodegradation, Vol.61(3), 214-222.

[71]. Leahy, J.G. and Colwell, R.R. (1990). Microbial Degradation ofHydrocarbons in the Environment. Microbiology Revolution, Vol. 54,305-315.

[72]. Levin, L., Viale, A. aand Forchiassin, A. (2003). Degradation of Organic Pollutants by the White Rot Basidiomycete Trametes trogii. International Biodeterioration and Biodegradation, Vol. 52, 1-5.

[73]. Mandri, T. and Lin, J. (2007). Isolation and Characterization ofEngine Oil Degrading Indigenous Microorganisms inKwazulu-Natal, South Africa. African Journal ofBiotechnology, Vol. 6(1), 023-027.

[74]. Mansur, M.M.E., Arias, J.L., Copa-Patino, M., Flärdh, M. and González, A.E. (2003). The White-rot Fungus Pleurotus ostreatus Secretes Laccase Isozymes with Different Substrate Specificities. Mycologia, Vol. 95, 1013-1020.

[75]. Margesin, R. and Schinner, F. (1999). Biological Decontamination of Oil Spills in Cold Environments. Journal of Chemistry, Technology and Biotechnology, Vol. 74, 381389

[76]. Marin, S., Sanchis, V., Ramos, A. and Magan, N. (1998). Effect of Water Activity on Hydrolytic Enzyme Production by Fusarium moniliforme and Fusarium proliferatum during Colonisation of Maize. International Journal of Food Microbiology, Vol. 42, 185-194.

[77]. McFarland, M.J., Qiu, X.J., Sims, J.L., Randolph, M.E. and Sims, R.C. (1992). Remediation of
Petroleum Impacted Soils in Fungal Compost Bioreactors. Water Science and Technology, Vol. 25, 197-206.

[78]. Mohd. Mozamil Bhat, Shiv Shsankar, Shikha, Mohammad Yunus and Shukai R. N (2011). Remediation of Hydrocarbon Contaminated Soil through Microbial Degradation - FTIR Based Prediction. Advances in Applied Science Research, Vol. 2(2), 321-326.

[79]. Muñoz, R. and Guieysse, B. (2003). Phenanthrene Biodegradation by an Algalbacterial Consortium in Two-phase Partitioning Bioreactors. Journal ofApplied Microbiology and Biotechnology, Vol. 61, 261267.

[80]. National Research Council (1985). Oil in the Sea: Inputs,Fates, and Effects. National Academy Press, Washington.

[81]. Nilanjana, D. and Preethy, C. (2011). Microbial Degradation ofPetroleum Hydrocarbon Contaminants: An Overview.Biotechnology Research International, Vol. 11, 13.

[82]. Obire, O. (1988). Studies on the Biodegradation Potentials of Some Microorganisms Isolated from Water Systems of Two Petroleum Producing Areas in Nigeria.Nigerian Journal of Botany, Vol. 1, 81-90.

[83]. Obire, O., Anyanwu, E.C. and Okigbo, R.N. (2008). Saprophytic and Crude Oil Degrading Fungi from Cow Dung and Poultry Droppings as Bioremediation Agents. International Journal of Agricultural Technology, Vol. 4, 81-89.

[84]. Okerentugba, P.O. and Ezeronye, O.U. (2003). Petroleum Degrading Potentials of Single and Mixed Microbial Cultures Isolated from Rivers and Refinery Effluent in Nigeria. African Journal of Biotechnology, Vol. 2(9), 288-292.

[85]. Okonokhua, B. O., Ikhajiagbe, B., Anoliefo, G. O., and Emede, T. O. (2007). The Effects of Spent Engine Oil on Soil Properties and Growth of Maize (Zea Mays L.). Journal of Applied 
Science in Environmental Management, Vol. 11(3), 147-152.

[86]. Olutiola, P.O., Famurewa, O. and Sonntag, H.G. (1991). AnIntroduction to General Microbiology: A PracticalApproach. HygieneInstitut Der UniversitatHeidelberg, 70-74.

[87]. Onwurah, I.N.E., Ogugua, V.N., Onyike, N.B., Ochonogor,A.E. and Otitoju, O.F. (2007). Crude Oil Spills in theEnvironment, Effects and Some Innovative Clean-upBiotechnologies. International Journal ofEnvironmental Research, Vol.1(4), 307-320.

[88]. Parrish, Z.D., Banks, M.K., and Schwab, A.P. (2004). Effectiveness of Phtoremediation as a Secondary Treatment for Polycyclic AromaticHydrocarbons(PAHs) in Composted Soil. International Journal ofPhytoremediation, Vol. 6, 119-137.

[89]. Perfumo, A., Symth, T.J.P., Marchant, R. and Banat, I.M. (2010). Productionand Roles of Biosurfactants and Bioemulsifiers in accessing hydrophobicsubstrates. Handbook of Hydrocarbon and lipid microbiology, Springer, Berlin.

[90]. Perry, J.J. (1984). Microbial Metabolism of Cyclic Alkanes," in Petroleum Microbiology, Atlas, R. M. (eds), Macmillan, New York.

[91]. Philippoussis, A., Diamantopoulou, P. and Zervakis, G. (2002). Monitoring of Mycelium Growth and Fructification of Lentinula edodes on Several Agricultural Residues. Mushroom Biology and Mushroom Products, UAEM, Cuernavaca, 279-287.

[92]. Prasad Shukla, K., Kumar, N.S. and Sharma, S. (2010). Bioremediation: Developments, Current Practices and Perspectives. Journal of Genetic Engineering and Biotechnology, Vol. 3.

[93]. Prenafeta-boldu, F.X., Luykx, D.M.A., Vervoort, J. and De Bont J.A.M. (2001). Fungal Metabolism of Toluene: Monitoring of Fluorinated Analogs by 18 F Nuclear Magnetic
Resonance Spectroscopy. Applied Environmental Microbiology, Vol. 67, 1030.

[94]. Prenafeta-boldu, F.X., Vervoort, J., Grotenhuis, J.T.C. and Van Groenestijn J.W. (2002). Substrate Interactions During the Biodegradation of Benzene, Toluene, Ethylbenzene, and Xylene (BTEX) Hydrocarbons by the Fungus Cladophialophora sp. Strain T1. Applied Environmmental Microbiology, Vol. 68, 2660.

[95]. Prescott, L.M., Harley, J.P. and Klein, D.E. (2002). Microbiology (5th ed). McGraw Hill Inc., New York, 20-38,96-132, 1012-1018.

[96]. Prince, R.C., R. Bare., Garrett, R.M., GarrettGrossman, M.G., Haith, C., Keim, L.G. and Guenette, C.C. (2003). Bioremediation of Stranded Oilon an Arctic Shoreline, Spill Science and Technology Bulletin, 303-312.

[97]. Rahman, K.S.M., Banat, I.M. and Thahira, J. (2002).Bioremediation of Gasoline Contaminated withPoultry Litter, Coir Pith and RhamnolipidBiosurfactant. Journal of Environmental Quality, Vol. 24, 19-28.

[98]. Reddy, C.A. and Mathew, Z. (2001). Bioremediation Potential of White Rot Fungi. Fungi in Bioremediation, Cambridge University Press, Cambridge.

[99]. Riser-Roberts, E. (1998). Remediation of PetroleumContaminated Soils. CRC Press, Boca Raton, Florida.

[100].Ritz, K., McHugh, M. and Harris, J. (2003). Biological Diversity and Function in Soils: Contemporary Perspectives and Implications in Relation to the Formulation of Effective Indicators. OECD Expert Meeting on Soil Erosion and Soil Biodiversity Indicators, Rome, $1-11$.

[101].Schaffner, D.W. and Toledo, R.T. (1991). Cellulase Production by Trichodermareesei when Cultured on Xylose-based Media 
Supplemented with Sorbose,Biotechnology and Bioengineering, Vol. 137, 12-16.

[102].Scheidegger, K.A. and Payne, G.A. (2003). Unlocking the Secrets Behind Secondary Metabolism: A Review of Aspergillus flavus from Pathogenicity to Functional Genomics. Journal of Toxicology, Vol. 22, 423-459.

[103].Schoen, S. and Winterlin, W. (1987). The Effects of Various Soil Factors and Amendments on the Degradation of Pesticide Mixture. Journal of Environmental Science and Health, Vol. 22, 347-377

[104].Schwab, A.P., Su, J., Wetzel, S., Pekarek, S. and Banks, M.K.(1999). Extraction of Petroleum Hydrocarbons fromSoil by Mechanical Shaking. Environmental Science and Technology, Vol.33, 1940-1945.

[105].Shimada, A., Kusano, M., Takeuchi, S., Fujioka, S., Inokuchi, T. and Kimura, Y. (2002). Aspterric Acid and 6-hydroxymellein, Inhibitors of Pollen Development in Arabidopsis thaliana, Produced by Aspergillus terreus.Journal of biosciences, Vol. 57, 459-464.

[106].Singer, M.E. and Finnerty, W.R. (1984). Microbial Metabolismof Straight-Chain and Branched Alkanes. Petroleum Microbiology, MacmillanPublishing Co., New York, 1-60.

[107].Singh, B.K. and Kuhad, R.C. (2000). Degradation of Insecticide Lindane (g-HCH) by White Rot Fungus Cyathus bulleri and Phanerochaete sordida. Pest Management Science, Vol. 56, 142-146.

[108].Smita, C., Jyoti, L., Vandana, S. and Chetan, S. (2012). Assessment of Diesel Degrading Potential of Fungal Isolates from Sludge Contaminated Soil of Petroleum Refinery, Haryana. Research Journal of Microbiology, Vol. 7, 182-190.

[109].Snape, I., Riddle, M.J., Stark, J.S., Cole, C.M. and Gore, D.B. (2001). Management and Remediation of Contaminated Sites at Casey
Station.Antarctica Pollution Records, Vol. 37, 199-214.

[110].Thavasi, R., Jayalakshmi, S. and Banat, I.M. (2011). Application of Biosurfactant Produced from Peanut Oil Cake by Lactobacillus delbrueckii in Biodegradation of Crude Oil. Journal of Bioresources Technology, Vol. 102, 3366-3372.

[111].U.S Congress (1991). Office of Technology Assessment.Bioremediation for Marine Oil Spills BackgroundPaper. U.S.Government Printing Office. Washington DC, 31.

[112].Ugoh, S.C. and Moneke, L.U. (2011). Isolation of Bacteria From Engine Oil Contaminated Soils in Auto Mechanic Workshops In Gwagwalada, Abuja, FCT-Nigeria. Academia Arena, Vol. 3(5), 28-33.

[113].Venosa, A. and Zhu, X. (2003). Biodegradation of Crude Oil Contaminating Marine Shorelines and Freshwater Wetlands Spill. Science Technology Bulletin, Vol. 8,163-178.

[114].Vidali, M. (2001). Bioremediation: An Overview. Pure and Applied Chemistry, Vol. 73, 1163-1172.

[115].Walker, J.D., Cofone L. and Cooney, J.I. (1973). Microbial Petroleum Degradation: The Role of Cladosporium resinae on Prevention and Control of Oil Spills. API/EPA/USLG Conference, Washington D.C., 89-140.

[116].Warshawsky, D. and Cody, T. (1995). Biotransformation of Benzo[a]pyrene and Other Polycyclicaromatic Hydrocarbons and Heterocyclic Analogs by Several Green Algae and Other Algal Species under Gold and White Light. Chemico-Biological Interactions Journal, Vol. 97, 131-148.

[117].Wiltse, C.C., Rooney, W.L., Chen, Z., Schwab, A.P. and Banks, M.K. (1998). Greenhouse Evaluation of Agronomic and Crude Oil Phytoremediation Potential Among Alfalfa 
Genotypes. Journal of environmental Quality, Vol. 27,169-173.

[118].Wischmann, H. and Steinhart, H. (1997). The Formation of PAH Oxidation Products in Soils and Soil/ Compost Mixtures. Chemosphere, Vol. 35, 1681-1698.

[119].Wu, T. and Crapper, M. (2009). Simulation of Biopile Processes Using a Hydraulics Approach. Journal of Hazard Mater, Vol. 17, 1103-1111.

[120].Zervakis, G., Philippoussis, A., Ioannidou, S. and Diamantopoulou, P. (2001). Mycelium Growth Kinetics and Optimal Temperature Conditions for the Cultivation of Edible Mushroom Species on Ligno- cellulosic Substrates. Folia Microbiology, Vol. 46, 231234.

[121].Zhu, X., Venosa, A. D., Suidan, M. T. and Lee, K. (2001). Guidelines for the Biodegradation of Marine Shorelines and Freshwaters. USA EnvironmentalProtection Agency Office of Research and Development National Riskmanagement Research Laboratory Land Remediation and Pollution Control,Cincinnati, Ohio, 312-320.

\section{Cite this article as :}

Laurelta Tudararao-Aherobo, Solomon Mesogboriwon, "Bioremediation of Spent Engine Oil Contaminated Soils Using Indigenous Fungi Species", International Journal of Scientific Research in Science and Technology (IJSRST), Online ISSN : 2395-602X, Print ISSN : 2395-6011, Volume 7 Issue 2, pp. 445-461, March-April 2020. Available at doi : https://doi.org/10.32628/IJSRST207156

Journal URL : http://ijsrst.com/IJSRST207156 